\title{
Interpretation of Nyadran Sonoageng Ritual as the Form of Ritual Communication of Sonoageng Villagers, Nganjuk Regency
}

\author{
Megasari Noer Fatanti ${ }^{1, a)}$ Siti Noer Tyas Tuti²) \\ ${ }^{1}$ Universitas Negeri Malang, Malang, Indonesia \\ a) author correspondence : megasari.fatanti.fis@um.ac.id \\ ${ }^{2}$ Universitas Brawijaya, Malang, Indonesia
}

DOI: https://doi.org/10.18196/jkm.121036

Article Info

Article history: Received 27 Nov 2018 Revised 16 Apr 2020 Accepted 5 May 2020

\section{ABSTRACT}

This study aims to reveal the meaning of the ritual Nyadran Sonoageng in Nganjuk, East Java. The ritual which has been carried out since 1995 is a traditional communication model (silaturahmi) in the social structure in Nganjuk and a medium of community communication with their ancestors. By using the theoretical framework about ritual communication, the researcher revealed that throughout the process of administering the ritual, there was the involvement of local government to form the discourse of the Nyadran itself. Through a new ethnographic approach that focuses on discovering how people organize their culture in thought and action, the final results of this study indicate that the ritual of Nyadran Sonoageng which initially was a representation of gratitude to God experienced an expansion of meaning as a communication medium and tourism commodity that could generate additional income for residents around Nganjuk Regency. Based on the results of participant observation and in-depth interviews, the researchers obtained a portrait of the meaning of Nganjuk residents on the Nyadran Sonoageng ritual. Interestingly, the active role of the religious leaders, religious leaders/traditional leaders is an essential factor in maintaining the memory of the conception of gratitude to God and ancestors through a performance of the Nyadran Sonoageng ritual.

Keywords: Belief System; Ritual Communication; Ethnography; Nyadran; Tradition

\section{ABSTRAK}

Penelitian ini bertujuan untuk mengungkapkan proses pembentukan makna ritual Nyadran di Desa Sonoageng Kabupaten Nganjuk, Jawa Timur. Ritual yang telah dilakukan sejak tahun 1995 ini merupakan salah satu bentuk komunikasi tradisional antara warga Desa Sonoageng dengan saudara, tetangga hingga leluhur yang sudah meninggal. Melalui kerangka teoretis komunikasi ritual James W. Carey, peneliti menguraikan bahwa dalam upaya pembentukan makna Nyadran terdapat pihak-pihak yang turut serta mendukung/melanggengkan makna ritual Nyadran Sonoageng tersebut. Bentuk pelanggengan tersebut diawali dengan penentuan tanggal penyelenggaraan Nyadran, rangkaian acara, pihak-pihak yang terlibat hingga proses pendokumentasian ritual Nyadran Sonoageng tersebut. Peneliti menggunakan pendekatan etnografi baru yang memusatkan pada penemuan bagaimana masyarakat mengorganisasikan budaya mereka dalam pikiran dan tindakan, hasil akhir penelitian ini menunjukkan bahwa ritual Nyadran Sonoageng yang awalnya hanya representasi rasa syukur kepada Tuhan mengalami perluasan makna sebagai medium komunikasi serta komoditas wisata yang dapat menghasilkan pendapatan tambahan bagi warga sekitar Kabupaten Nganjuk. Berdasarkan hasil observasi partisipan dan wawancara mendalam, peneliti mendapatkan potret pemaknaan warga Kabupaten Nganjuk atas ritual Nyadran Sonoageng tersebut. Menariknya, peran 
aktif dari pinisepuh, tokoh agama/tokoh adat menjadi faktor penting dalam pemeliharaan ingatan akan konsepsi rasa syukur kepada Tuhan dan leluhur melalui penyelanggaraan ritual Nyadran Sonoageng tersebut.

Keywords: Etnografi; Komunikasi Ritual; Nyadran; Sistem Kepercayaan; Tradisi

\section{INTRODUCTION}

Communication is constitutive of culture, and no culture can live without communication. Communication is also essential for the social order of society (Dissanayake, 2003). Concerning the relationship between communication and culture, Hall (1959) argued that culture is communication and communication is culture. Communication and culture are two inextricable concepts. The central concern of communication and culture lies in the variety of stages and human methods in communicating in a human community or social group.

The sociocultural approach in the communication theory shows that understanding of meaning, norm, roles, and rules work interactively in communication (Cloud, 1994 in Littlejohn and Foss, 2011). This tradition explains that reality is created from a process in the group, community, and culture. Sociocultural tradition tends to address how meaning is fabricated in social interaction. Interaction is a process and medium of meaning, roles, rules, and cultural value that is adhered to (Littlejohn and Foss, 2011). Morrisan (2013) explained that culture can be seen in virtue of social interaction, and eventually, culture can provide the context of action and interpretation in a communicational situation.

One of the instances of culture in Javanese society is ritual for the predecessor and welfare, widely called as Nyadran. Nyadran ritual is usually conducted in the month of Ruwah and becomes a part of the traditional ceremony, which is brim with the use of symbols as communication media. The symbols are media that stems from the ancestors to describe any forms of messages that contain knowledge for society as the next generation. The definition of the traditional ceremony, according to the Regulation of the Ministry of Education and Knowledge of Republic of Indonesia Number 10, 2014, article 4, is a sacred event that is associated with a power higher than human (ghaib), natural event, and life cycle. The definition of nyadran, on the other hand, according to Poerwadarminto (in Alifiana, 2013), is a ritual (asking for welfare) in a sacred place (selamatan (sesaji) ing papan sing kramat). Traditional practice is believed as communication media between the living and the dead, and controllers, even social regulator. It is reflected by the anthropological and communication description originating from a particular cultural practice (Poranannond, 2015; Wagner, 1984).

Citing Nugroho (2015), the arrival of Hinduism influences the ritual practice towards the ancestors, primarily the social system of Javanese society. So too with Islam that also influences the implementation of Sraddha ritual or widely known as sadran or nyadran, i.e., a ritual to show gratefulness of blessing bestowed by the only God and a medium to reminisce the past ancestors. The researchers see that Sadran resulted from cultural acculturation of Hinduism-Islam that have been proceeded since hundred years ago. Based on the pre-research observation through the reading of text/documentation, the acculturation forms are reflected from the use of prayer (with the recitation of Al-Qur'an's verse and tahlil) and offerings (sesaji) during the ritual.

Nyadran tradition is still found in some places in Java Island, such as Central Java and East Java. Some of the regions that carry out nyadran are Gunung Balak (Magelang), Balongfowo (Sidoardjo) Suruhan (Semarang), Ngantru (Trenggalek), and Sonoageng (Nganjuk). Each region has a different historical background in determining when and where nyadran ritual should be conducted, although, in general, the execution is in the month of Ruwah (Handayani, 1995). Take nyadran in Ngantru Village; the nyadran is conducted in Kliwon Friday in the month of Selo (Javanese) annually. It is called Nyadran dDam Bagong and aims to reminisce about the kindness of Adipati Menak Sopal that constructed a dam to suffice the water needs in the village. The local activity during Nyadran Dam Bagong is that the locals do not take a shower and have activity around the dam (Anggraini, 2017). Another example is nyadran in Balak Mountain, Magelang City. Nyadran is still performed by the society every Kliwon Tuesday in the month of Suro (not Javanese). Balak Mountain people try to preserve the tradition by involving pinisepuh desa (the elders), village officials, and the residents 
(Kusiniati, 2013). One of the aims of the nyadran is to show sincere gratitude towards the God and village ancestors that have protected society from undesirable events.

However, of other instances of nyadran, nyadran in Sonoageng involve the younger generation in the preparation to the execution of the nyadran. It is line with James W. Cary argument that communication is not merely a one-way transmission but also symbols interconnections in a particular culture and produces shared interpretation. Nyadran Ritual which is full of symbol use is ascribed to custom or culture to provide, hopefully, an understanding for the society who use it (Wuryansari, Lestari, and Isbandi, 2014). According to Littlejohn (!996:64), symbols are the foundation of all communication processes. Humans by means of symbols communicate with each other; otherwise, humans would not be able to communicate. Under the statement, Susanne Langer (Littlejohn, 1999, 68) stated that communication symbols are spread massively thorughout world, and the traditional ceremony is one the communication symbol within the world which also function as the realization of culture.

The researchers found it essential to study the ritual of sadranan as an attempt to preserve local knowledge of society. Research that focuses on the aspect of local, traditions, and rituals, aims to maintain the collective memory of individuals and assert that old-fashioned does not indicate futileness. Citing Schuler (2014), it is argued that knowledge or local culture functions similarly to natural sciences. One of the functions is the capability to explain natural phenomena in which natural sciences abstain to explain. Therefore, religion provides numerous models that show relations between humans and the environment. Consider animism; for them, tress is a social sphere that is sensitive to human action. The researcher argues by considering the premise mentioned that contribution of social knowledge is not only to counter a discourse regarding globalization but also as a communication strategy of humans and nature.

By employing the framework of James W. Carey on communication as ritual and theory of symbolic interactionalism of Herbert Blumer, the researcher aims to reveal the meaning and the process of the tradition of ritual Nyadran Sonoageng, which is conducted by the residents of Sonoageng Village, Nganjuk Regency. Coupled with the ethnography approach and live-in-with-thelocal strategy to obtain comprehensive information regarding the implementation of Nyadran Sonoageng, the researcher found some findings, and the presentation will be divided into four points. Firstly, the research will explain the history of the tradition of Nyadran Sonoageng in Sonoageng Village, Prambon District, Nganjuk Regency. Secondly, it will be argued that the preparation of nyadran involves not only the older generation, such as the elders, religious leaders, and village officials, but also the male and the female younger generation of the village. Thirdly, the researchers will analyze how the locals interpret the ritual of Nyadran Sonoageng. It is later shown that it is a form of showing sincere gratitude to God and village ancestors. Finally, the researcher will conclude that the tradition or ritual that still exists within society, whether in Java Island or other regions, is essential to be published as an attempt to preserve local values. However, the researchers admit that not all dimension in the tradition or ritual of Nyadran Sonoageng has been explained. Therefore, a further study is needed, mainly that focus on how to revitalize local traditional values of Nyadran Sonoageng.

\section{METHODS}

The research adopted ethnography research principles by putting forwards active-participative observation techniques and in-depth interviews in data collection that taking place for six months in Sonoageng Village, Prambon District, Nganjuk Regency. The ethnography method also required the researchers to reside (live-in) with the locals to obtain the most natural topography of the data. Regarding that requirement, the researchers, who are also residents of the Sonoageng Village, have more access to information concerning the Nyadran Sonoageng ritual. The research stages started with indirect observation to map the situation and actors that would be involved to be the informant. Secondly, the researcher listed and recorded the name and roles of the informants, and observe the preparation of the ritual of nyadran that took place around a month. Thirdly, the researcher visited the informant individually to conduct in-depth interviews regarding their understanding, involvement, roles, and interpretation of the nyadran ritual. Fourthly, the researcher recorded the observation results and interviews routinely to the field notes to find a theme analysis in each interview point. For example, since the researchers planned on analyzing the local understanding of the Nyadran Sonoageng's ritual, the questions were the time the informants have lived in the village, the 
involvement in the nyadran ritual preparation, the role in the activity, and the method to conserve the meaning of nyadran in the family and social environment.

The research selected informants through random sampling. One of the reasons is that the information that was given by the individual needed intensification. Some informants that were involved in the research are as follows:

1. The village bayan of Sonoageng. Bayan or kabayan is a person in charge of the skills and potency development of the village. Bayan here is a resident of Sonoageng Village that understands history, procession, and nyadran.

2. The Sonoageng's elder, including the caretaker of Mbah Sahid's graveyard, called Mbah Bayan;

3. The Sonoageng's village head that always contributes to every villager activities;

4. The youth organization's head of Sonoageng. In this research, the person provided information regarding the role of the younger generation of Sonoageng in the sadranan activity.

5. The Department of Culture, Tourism, and Sports's staff in Nganjuk Regency. The staff is interviewed to analyze the involvement of the department (government representation) in Nyadran Sonoageng's ritual.

These five informants were visited by the researcher individually and needed around six to eight months. Limitation in language, time, to reluctance in telling the story of the history of sadran Sonoageng led the researchers to some alternatives. One of them was by studying archives and past research regarding Nyadran Sonoageng. During the participative observation, the researcher succeeded in documenting the preparation of the Nyadran Sonoageng ritual to the main event of the ritual itself.

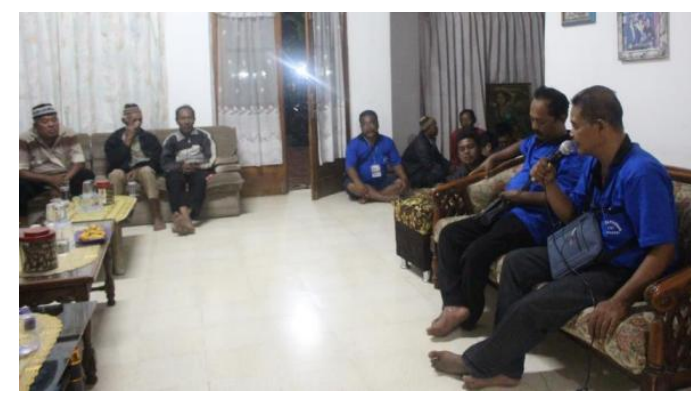

(a)

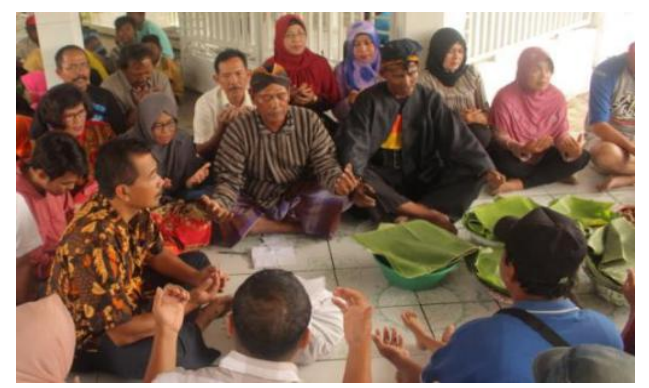

(b)

Figure 1. (Left-Right) Preparatory Meeting for Nyadran Ritual and Feast in Mbah Sahid's Tomb (source: Personal Documentation, 2017)

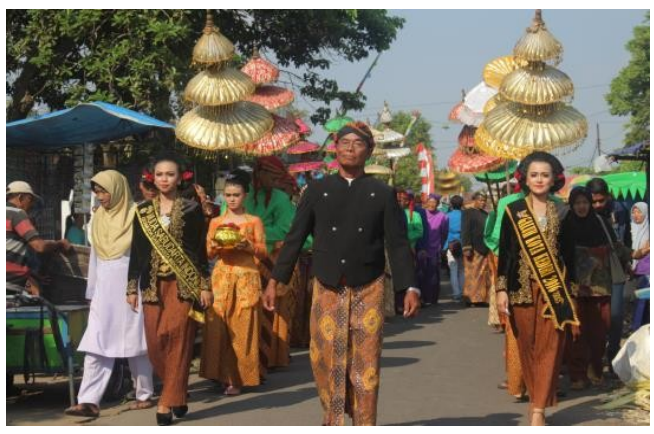

(a)

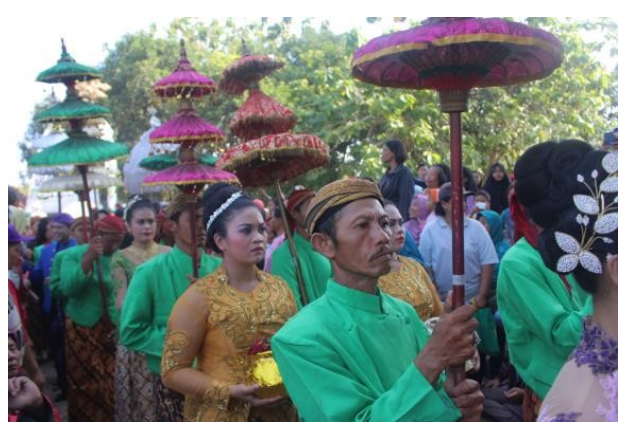

(b)

Figure 2. (Left-Right) The Nyadran Sonoageng Ritual (source: Personal Documentation, 2017) 


\section{RESULT AND DISCUSSION}

Carey (2009) developed communication within cultural perspectives and saw that is related to an attempt to create and maintain the community. Carey (Ross, 2013) described a 'stripping' phenomenon, namely 'text' or other symbolic activities that need to be translated to comprehend the meaning behind it by using an interpretative approach. The interpretative approach predicts the social meaning of an individual in a specific group in a cultural atmosphere. According to the interpretative approach, individual act to choose stems from various cultural contexts in which individuals interact with others. The assumption is that meaning given by individual who interacts in a certain cultural situation enables differences in meaning that is given by the other individuals from other culture (Malik \& Pereira, 2016).

Furthermore, a ritual perspective shows that communication creates the reality of a group. Carey (ross, 2013) asserted that reality is created collectively by individuals in a conversation involving all the members. The ritual communication perspective explained that social reality is created through symbolic interaction of society (Ross, 2013). Furthermore, Grossberg (Ross, 2013) contended that ritual communication concepts provide a general image on the interaction between communication, community, and the union that does not only explore the communication' means in creating symbolic reality but also defined individuals' means in interacting and participating with other individuals in reality.

\section{Ritual Communication Perspective in the Communication Study}

James W. Carey, a social theorist that initiates the concept of communication in the ritual perspective, explained that communication is a process in a collective culture that is created, modified, and transformed. The definitions of ritual are associated with communication terms, such as sharing, participation, association, fellowship, and possession of a common faith. The ritual communication perspective does not aim to extend messages within the sphere as in the level of transmission communication but to preserve social meaning across time. It is not an action to indoctrinate information, but to represent shared beliefs.

Senft and Basso (2009) argued that ritual communication is an action or attempt to involve knowledge regarding local culture in human interactions. If a ritual is a communication form, the roles of ritual in culture should be analyzed collectively by the individuals outside the culture (Robbins, 2001). A ritual can be defined as a series of repeated activities, cultural punishment, and routine that presuppose supernatural beings, such as spirit and gods (Gilmore, 1998; in Poranannond, 2015). Bradshaw and Melloh (2007) identified a ritual as a different activity from other typical actions. The objective of a ritual is to serve the collective needs of society, such as group solidarity preservation, group values practices, multiculturalism maintenance, and social category that may contain social conflicts. Also, it facilitates the transition of categories in social life (Poranannond, 2015). In the context of Nyadran Sonoageng, the ritual is, the researcher argues, about how symbols in a particular situation function as a mediator of understanding of objects.

\section{Nyadran Ritual in the Social Communication of Javanese People}

After Islam was introduced to Indonesian in the 13th century, Islamic religious leaders called the Wali Sanga (The Nine Sages) started to amalgamate local tradition and Islamic canons. The reason is not to clash local beliefs and traditions and let Islam be accepted more smoothly to society. Wali Songo tried not to alter the existing habits of society and harmonize it with Islamic doctrines. As a result, there exist local tradition that resulted from assimilation and acculturation of Hinduism, Buddhism, and other local knowledge. During the Hinduism-Buddhism era, the tradition of nyadran was known as craddha, and people recited praise and displayed offerings as ritual instruments. After Islam, al-Quran recitation, tahlil, and prayer, as well as eating together (feast) called kenduri changed the old habits (Mumfaganti, 2017). However, the observation showed that, during nyadran, the people also did not leave offerings, such as kembang setaman (funeral flowers), myrrh or incense, king banana, and ivory coconut.

For Javanese, nyadran is an annual event functioning as a socio-religious reflection. Alifiana (2013) explained that the Javanese treasure their cultures' virtue and noble values. This is the reason nyadran practices incorporate Hindusim-Buddhism and Animism aspects, that was acculturated with Islamic values due to Wali Sanga. Nyadran, in the month of ruwah, or customarily recognized as sadranan or sometimes named ruwahan, is a typical tradition in the life of Javanese society 
(Handayani, 1995). Nyadran is an ancestors' belief that is still conserved by the Javanese people to revere their ancestors. Nyadran is a special event for pilgrimaging (cleaning the graveyard, nyekar) to the ancestor's graveyard. Indirectly, this event used by the families to reunite (Priyanto, 1988). Nyadran tradition has attracted researchers to study it. For example, a study by Arnez (2010) demonstrated that nyadran is deemed similar to craddha tradition conducted in the Majapahit era, primarily in how they revere the ancestors.

In general, rural people in Java Island conduct nyadran concurrently. This ritual is often interpreted as an activity that strengthens relations between God, ancestors, society, and life and death. Some villages in Central Java Province even conduct Nyadran for two whole days before the end of the month of Ruwah. Nyadran ritual can take place in village ancestor tombs or Muslim cemeteries that are considered essential in spreading Islam in the location. Indeed, in some places, the ritual of nyadran is performed in the village mosque. The authority in the region determines the decision for location and execution. The elders, religious leaders, shaman, or village officials play a significant role in it.

Parji (2016) studied nyadran in Tawun, the biggest nyadran in Ngawi. Apart from showing that the ceremony is conducted yearly and involves all residents in Tawun Village, it showed that nyadran in Tawun Village five functions. The first is as the expression of gratitude of villages to the only God that has bestowed protection and blessing so that the people can live in peace and reap enormous harvests. The second is to show gratitude to the ancestors (founder of the village), which, mythologically, is called as danyang ingkang mbaorekso or predecessor spirits that protect the village for being safe and peaceful. Thirdly, it figures in raising unitary feeling and solidarity among people. Fourthly, it is useful to show the religious value through prayers and, fifthly, it functions as showing cultural value through traditional arts as the accompanists of Nyadran. This event can also have economic value since it can be a tourism destination that increases people's and the government of Ngawi Regency income. Not far different from other types of nyadran, the date decision of the ceremony should be made correctly. According to people's beliefs, an incorrect date decision may engender undesirable outcomes (Yusantari, 2017).

Parji (2016) explained that nyadran is a form of belief regarding particular sacred places, and also considered animism or dynamism. The belief had existed before Hinduism, Buddhism, and Islam were introduced to Indonesia. Nyadran tradition is a fusion of Hinduism and Islam. Hinduism elements are shown through the use of incense and flowered water, while Islam elements are reflected from the prayer for welfare. It can be said that the nyadran procession sustains harmonic values between nature and human, human and God, and socio-cultural values.

\section{The history of Nyadran Sonoageng}

Nyadran Sonoageng is conducted on Legi Thursday on the evening before Pahing Friday in June or July or when the second rice harvest. Javanese people call this with walikan harvest. If there is no Legi Thursday in June, the event will be conducted in July. In addition, if Ramadhan takes place in June or July, the nyadran will be postponed to after Ied Fitri Day or brought forward before Ramadhan. Nyadran Sonoageng procession is a tradition that is initiated by the residents since 1994. Through the process, some myths appear regarding symbols in the ritual. As explained by Hobsbawm (1983), myths are created, established, and institutionalized formally, characterized by ritual or symbols, and attempts to instill norms and values to the actors.

Based on the researchers' investigation regarding the practice of Nyadran Sonoageng, there was no exact information about when the nyadran was started. An interview with an informant, namely the caretaker of the tomb of Mbah Sahid, who is deemed as a founder of the villages, Nyadran Sonoageng has been performed since he was still a child.

If I remember it, it has happened since I was a little. But, it was simple since, importantly, we conducted a feast... It has been there since I was a little, but the entertainment form that the Grandpa loved the most was only krucil puppet and kentrung. Another entertainment form is only added from the people that follow the development, just to make it aggrandize. (Mbah Bayan, Personal Interview, March 2017).

Nyadran Sonoageng was interpreted differently by the people, mainly in terms of history or society belief towards ancestors. On the one hand, some people believed that this ritual had an agenda 
to introduce the history of Mbah Sahid as the village founders. On the other hand, some people disagreed with the agenda and believed in the version related to the life of Pangeran Diponegoro. Two sites were considered as tombs of the village founders, the tomb of Mbah Sahid and the tomb of Syech Wahdzat. Different understanding of the history of babad alas desa (establishment of the village) induced two interpretations of nyadran. The researchers found a difference in conducting nyadran among the residents of Sonoageng, a difference between resident that believed in Mbah Sahid's history and those who believed in Syech Wahdzat. However, Nyadran Sonoageng was conducted concurrently by the residents of Sonoageng. The following is a passage from the interview with the caretaker of Mbah Sahid's tomb:

Overall, a feast or kenduri at the tombs at the Syech Wahdzat's tomb and a site considered as Mbah Sahid's tomb located in the middle of the public cemetery of Sonoageng, is essential in nyadran procession. The procession then was continued with a carnival from the village meeting hall to the public cemetery by bringing offerings. It was followed by flower sowing ceremony (nyekar) and reciting prayers by the elders. Afterward, in the evening, an art performance and people market were conducted. The nyadran was participated by residents of Sonoageng, including the village officials, government institutions that supervise the village, Prambon District Chief, Nganjuk's Regent, Local Police and Army, Department of Culture and Tourism (Disbudpar) and other people outside Sonoageng. For most Sonoageng's residents, nyadran was a means for families' members to gather. Also, nyadran gave birth to many myths in society. For example, the residents believed that by carrying out Nyadran, the village would be protected from disasters and obtain more fortunes. However, some performances were considered mandatory during nyadran, namely krucil puppets and kentrung. Nevertheless, other performing arts also participated in nyadran, such as shadow puppets, ludruk, reog, jaranan and tayuban. People's enthusiasm was evident in this event by performing keroncong music, people market, and gymnastics.

\section{The Objective of Nyadran Sonoageng}

Sonoageng people contended that the objective of nyadran tradition is to express gratitude after a big harvest. However, there are other objectives. Reminiscing the service of Mbah Sahid as a person that found or establish (Babad Alas) of Sonoageng Village is one of them for some people. It was conducted on either Legi Thursday in either June or July. In the event, there was an activity to clean the site considered as the tomb of Mbah Sahid.

Nyadran tradition aims to express people's gratitude towards the creator for its blessing, which can be a fortune or health for the member of the family. Principally, nyadran means to be grateful or accepting what God has given. Sonoageng people believed that with the nyadran tradition, the future life would be more desirable and prevented from disaster, both for the village or family, and peaceful and bliss.

Nyadran has been held since the Hinduism-Buddhism era by Javanese people. As one of the cultural forms in Java, nyadran should be conserved and preserved since the tradition involves some performing arts, namely jaranan, ludruk, shadow puppet, krucil puppet, kentrung, tayub, and reog. A tradition unconsciously provides identity to the traditional practitioner since each tradition, despite the similarity with other regions, has differences in terms of practices. It is one of the forms of diversity in Indonesia.

Furthermore, nyadran, conducted in Sonoageng Village, comprised noble values, such as gotongroyong (cooperations) in the society, to unite people's relationships amid disunity issues. Nyadran has united the people because, through performing nyadran, the people were more communicative with other people. Nyadran was inseparable from the roles of the younger generation. Advancement in civilization has changed nyadran in terms of the involvement and creativity poured by the younger generations. Not only the older generation, the younger generation also actively contributed to nyadran.

As a means to show gratefulness, nyadran was still preserved by the Sonoageng residents that have not resided there anymore. For example, some people who had moved or transmigrated (to outside Java) still send an amount of money for contributing to ingkung (a whole-body roasted chicken) for the feast at the Mbah Sahid's tomb. Based on the researcher's observation, there was no obligation for the people of Sonoageng to present the ingkung at the tomb of Mbah Sahid. It was a purely voluntary action. 


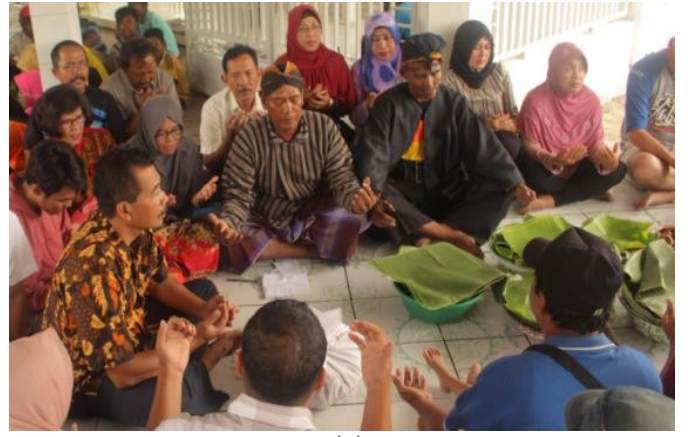

(a)

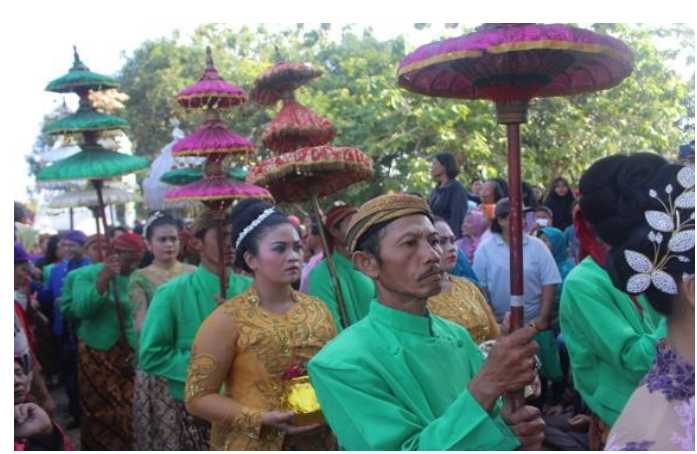

(b)

Figure 3. Feast at Mbah Sahid's tomb (left), Nyadran Sonoageng procession (right) (source: Personal Documentation, 2017)

\section{Reminiscing the Ancestor (Danyang) Through Nyadran Sonoageng}

Some Sonoageng people assumed Nyadran Sonoageng as a village cleansing or Pahing Friday ritual to revere the service of Mbah Sahid. Nyadran was conducted modestly by pilgrimaging to an allegedly Mbah Sahid's tomb and performing krucil puppet and kentrung. Some residents believed that krucil puppet is the Javanese art loved by Mbah Sahid and the core of the Nyadran procession. Nyadran originated from people's gratitude towards fortune and health, and the nyadran was conducted on Legi Thursday evening before Pahing Friday during the second rice harvest. The residents called the harvest as walikan. Those days, Legi Thursday and Pahing Friday were believed by the residents as the day when Mbah Sahid past away. However, for residents who believed in the version of Syech Wahdzat, nyadran was a form of reverence towards another village ancestor, Syech Wahdzat. It was fulfilled by conducting a pilgrimage and krucil puppet, which narrated a flag in the tomb of Syech Wahdzat.

\section{Ritual as a Medium to Establish Communities}

In sustaining the tradition and meaning of nyadran, many parties in Sonoageng contributed. Carey (2009) contended that communication from the perspective of culture is highly related to the attempt to develop and maintain the community. The culture of Sonoageng that is abundant with beliefs in ancestors, supernatural beings, and myths makes nyadran as a ritual hard to be abandoned by Sonoageng people. The creation of communities is a step to maintain the ritual and meaning containing in it. Carey (2009) explained that communication is a symbolic process to create, maintain, fix, and transform reality, and it is found that the people of Sonoageng attempted to create and maintain the meaning, as well as to fix the tradition. It is manifested in modified procession to attract people's attention. The attempts of Sonoageng people in maintaining, fixing, transforming meaning were realized in this form of communities.

\section{From Putro Wayah Eyang Sahid Community to Jumat Pahing Community}

In 1990, Nyadran's post was established. In 2005, then, it was developed to Putro Wayah Eyang Sahid Community before, in 2007, transforming as the Jumat Pahing Community. The members of the community were Sonoageng people that believed in the history of the village that relates to Mbah Sahid as the village ancestors. Putra Wayah Eyang Sahid figured in taking care of the sites deemed as Mbah Sahid's tomb, such as cleaning and looking after the tomb.

Putra Wayah Eyang Sahid transformed into the Jumat Pahing Community, which was formed in 2007 and aimed to succeed Nyadran Sonoageng. The role of the Jumat Pahing Community as the organizer of nyadran in Sonoageng is crucial. This community coordinated anything related to the event to ensure that event works smoothly, starting with preparing the location, determining the officers in the procession, organizing the who, security, to guests.

Jumat Pahing community was composed of the residents of Sonoageng that were conscious of the importance and the development of nyadran every year. The variation of the entertainment forms varied every year, depending on the residents' meeting in the community. It was one of the participation of the people in the form of interpersonal communication in a community as the medium 
to celebrate the nyadran ritual. Finally, through this community, the members and the people interacted and designed the plan for nyadran to be more rousing and capable of inviting visitors. The community was also formed because of dissatisfaction with the simple ritual.

\section{The Community for Syech Wahdzat Tomb Sympathizers}

The same activity was also done by the people that did not believe in the Mbah Sahid version of history. They formed another community that figured in taking care of the tomb and preserving the historical value of Syech Wahdzat's tomb. The caretaker of Syech Wahdzat tomb elicited the story of Syech Wahdzat from his predecessor with all the chronology and history for which his predecessor found the tomb of Syech Wahdzat in the current location, which was the field of the house of caretaker. Until now, the Syech Wahdzat story was passed down to the next generation, including the people who visited Syech Wahdzat and asked the history of the person. The sites of Mbah Sahid and Syech Wahdzat were sacred locations for the residents. Belief toward the two sites had the residents establish a community or union based on their understanding and faith. It is similar to what Carey (2009) explained that the phenomenon of communication ritual is a holy ceremony that can attract individuals to gather in a shared membership. The establishment of these communities is a result of the resident's attempts to maintain their belief towards ancestors. Grossberg (in Ross, 2013) explained that ritual communication concepts provide a general representation of the relationship between communication, community, and union. It explores not only how communication creates symbolic reality but also defines how individuals interact and participate with other individuals in reality.

The ritual communication perspective does not aim to extend the messages within a sphere as in the level of transmission communication but to preserve social meaning across time. It is not an action to indoctrinate information but to represent shared beliefs. Besides creating communities aiming to maintain the existing tradition, some residents of Sonoageng preserved the value and meaning of the nyadran through word of mouth. The contents mostly are the constructed history passed from generation to generation, and one person to another. The myth was not only believed by the Sonoageng residents but also by the sellers that came during Nyadran. Apart from looking for some earnings during nyadran, the sellers planned to get fortune (Informant 7, 2017).

These two figures were perceived as the danyang (ancestor) and babad alas (founder) of Sonoageng by the followers and believers. The two sites of the figures played significant roles in the nyadran performed by the surrounding residents since these two sites were parts of the meaning forming-process of nyadran. They figured in the expression of reverence of the people. Owing to that, the people put offerings, pilgrimaged, and decorated the tombs with flowers (nyekar). Nyadran was deemed a holy ceremony by Sonoageng people, and some of them still believed in the myths. They believed that if they did not do nyadran, disaster, or undesirable events would afflict them. The myth compelled the people to believe nyadran as sacred and cannot be abandoned.

Communication is related to some concepts, ranging from sharing, participation, union, membership, and a shared belief in the perspective of ritual (Carey, 2009). The concepts can be seen in the process of Nyadran Sonoageng, starting from the preparation to the execution. The participation and meetings of the people are essential for the realization of Nyadran Sonoageng. Through participation and meeting, values and symbols in the nyadran were distributed to create meaning in the society. As regards ritual, Poranannond (2015) explained that a ritual as an activity transmits meaning with the symbolic approach. The ritual of symbolic expression enables people to share shared values and aims. It is also a social activist and, in the implementation, needs individual cooperation.

\section{Nyadran Sonoageng in the Span of Meaning}

Ritual communication is a reference that is instilled in direct experience of the individual by social life and ritual action as an element of social experience (Arno, 2003). Carey (2009) explained that meaning and term are shelled to witness a real thing in existence. Meaning is a representation of experience, and that experience is communication. The meaning then would be interpreted through specific terms (Carey, 2009). In general, meaning formed in ritual communication is shared meaning before asserted in a language in a culture (Arno, 2003). Nyadran is a ritual that is considered sacred by the residents Sonoageng. Nyadran has a significant meaning that affects beliefs and practice. The meaning of nyadran is not limited to attributive uses during the ritual. 
1. Nyadran for Reminisce the Service of Ancestors

Some Sonoageng residents assumed Nyadran Sonoageng as village cleansing or Pahing Friday ritual to revere the service of Mbah Sahid. The residents carried out nyadran modestly by visiting the alleged tomb of Mbah Sahid. The motive of Nyadran Sonoageng was to show the gratitude of the people regarding the health and fortune they have earned. Nyadran was performed on Legi Thursday evening before Pahing Friday during the second rice harvest, or the people call it, walikan. That time was chosen since many people believed it was the day when Mbah Sahid passed away.

2. Jolen Offerings as an Expression of Gratitude and Chasing for Fortune of Sonoageng People

Jolen offerings were the central icon in the procession of Nyadran Sonoageng. Jolen was carried to the sites of Mbahs Sahid's tomb and accompanist with gamelan mungdhe (traditional music). The jolen was composed of crops of Sonoageng people, such as rice, corn, yam, fruits, vegetables, and kitchen tools. The composition of the jolen was an expression of gratitude to God. The residents hope to always remain healthy and fortunate after performing nyadran (Informant 6, 2017). The jolen that was carried was chased by the audience afterward to get the fortune from the jolen.

\section{Feast (Kenduri) and Praying Together (Tahlilan) as Media to Pray and to Chase for Fortune}

Most of the people in Sonoageng believed that by conducting kenduri (feast) by bringing offering such as roasted chicken and the miscellaneous at the Mbah Sahid's tomb, all the wishes would come true. The feast was conducted at the Mbah Sahid's tomb and led by the caretaker of the tomb. The recited prayers in the feast were presented to God to make the wish granted via Mbah Sahid and Syech Wahdzat. The prayers that were recited are a combination of Javanese and Al-Quran's verse. Ngalap berkah (chasing for fortune) in the feast was done so that Allah SWT can grant any wishes they asked. Not different from the feast (kenduri), tahlilan is a medium to pray to Allah SWT. The objective in this context was to alienate the village from disaster and to send a prayer to the ancestor of Sonoageng, which was not limited to Mbah Sahid and Syech Wahdzat. If the feast was small-scale, the tahlilan should be done on a large-scale.

\section{Nyadran as Media to Connect and Gather the Family}

Nyadran Sonoageng was a medium not only to chasing fortune (ngalap berkah) and an expression of gratitude but also for strengthening relationships or family gatherings. People who had moved to other regions spared their time to attend the nyadran. The people of Sonoageng, who most of them were Islam, even argued that the enthusiasm of the residents towards nyadran was more intense then Ied Fitri Day.

\section{Ziarah Makam atau Nyekar sebagai Penghormatan Terhadap Leluhur}

Nyadran Ritual procession includes pilgrimage (nyekar). Nyekar is done by praying and flowering on the graveyard. It aims to revere the ancestors that serviced the village in the past. The different constructions of the history of the ancestors in Sonoageng people induce differences in the activity in pilgrimage or nyekar during nyadrang.

\section{Pilgrimaging on the Mbah Sahid's Site}

Pilgrimaging during Nyadran Sonoageng, for the residents, figures in respecting Mbah Sahid's service in establishing the village. Pilgrimaging on the Mbah Sahid's site is a series of the precession of Nyadran Sonoageng.

\section{Pilgrimaging on the Syech Wahdzat's Tomb}

On the other hand, some people that believed in Syech Wahdzat visits the tomb of Syech Wahdzat, but not as a part of the procession of Nyadran. It is different from pilgrimaging on the Mbah Sahid's site; the pilgrimage in Syech Wahdzat's tomb is not only carried out by Sonoageng residents but also residents from other villages. Apart from visiting and praying, they often came to mediate. Pilgrimage on the tomb was not made solely during nyadran but also anytime the visitors of the tomb had a particular wish. 


\section{CONCLUSION}

Nyadran Sonoageng was interpreted by the residents through terms such as pilgrimage (nyekar), gratitude (syukur), chasing for fortune (ngalap berkah), and relationship strengthening (silahturtahmi). The people represented the terms through real actions and mindfulness in nyadran. Village cleansing was represented in the praying session during the feast on the tomb. The term nyekar or pilgrimage was manifested as the reverence towards the village founders, whether on Mbah Sahid's site or Syech Wahdzat's tomb. The people realized the terms of gratitude and appreciation by carrying jolen offerings during nyadran. Nyadran was also a medium to connect and gather with the family members who lived far and near the village. Nyadran ritual was impossible without the participation of various social elements and government roles, ranging from the village officials to regency officials. The people's participation can be seen in the people market, the preparation of nyadran, the rousing of Nyadran performing arts, whether it is modern or traditional. Nyadran ritual was performed together by the resident of Sonoageng without considering their beliefs of the real historical values.

\section{REFERENCES}

Alifiana, W. N. (2013). Perubahan Budaya dalam Tradisi Nyadran di Kelurahan Ngantru Kecamatan Trenggalek Kabupaten Trenggalek Jawa Timur. ADITYA-Pendidikan Bahasa dan Sastra Jawa, 2(1), 104-116.

Anggraini, N. S (2017). Nilai Kearifan Lokal dalam Tradisi Nyadran Dam Bagong di Kelurahan Ngantru Kecamatan Trenggalek, Kabupaten Trenggalek. SKRIPSI Jurusan Pendidikan Pancasila dan Kewarganegaraan-Fakultas Ilmu Sosial UM.

Hecht, R. D., \& Biondo, V. F. (2010). Religion and Everyday Life and Culture [3 Volumes]. ABCCLIO.

Arno, A. (2003). Aesthetics, intuition, and reference in Fijian ritual communication: modularity in and out of language. American Anthropologist, 105(4), 807-819.

Bell, G. C., Weathers, M. R., Hastings, S. O., \& Peterson, E. B. (2014). Investigating the celebration of Black Friday as a communication ritual. Journal of Creative Communications, 9(3), 235251.

Carey, J. W. (2009). Communication as culture, revised edition: Essays on media and society. Routledge.

Creswell, J. W (2014). Research Design: Qualitative, Quantitative and Mixed Methods Approaches. Sage Publications.

Darmawan, K. Z. (2008). Penelitian etnografi komunikasi: tipe dan metode. Mediator: Jurnal Komunikasi, 9(1), 181-188.

Dissanayake, W. (2003). Asian approaches to human communication: Retrospect and prospect. Intercultural Communication Studies, 12(4), 17-38.

Hall, E. T (1959). The Silent Language. Garden Cuty.

Handayani, T (1995). Tradisi Nyadran dan Perubahan Studi Kasus di Desa Daleman, Jurangrejo, Kecamatan Karanganom, Kabupaten Klaten.

Cushman, D. P., \& Kincaid, D. L. (1987). Introduction and initial insights. In Communication Theory (pp. 1-10). Academic Press.

Katriel, T. (2015). Expanding ethnography of communication research: Toward ethnographies of encoding. Communication Theory, 25(4), 454-459.

Kuncoro, Y. A. (2018). Komunikasi Ritual Garebeg di Keraton Yogyakarta. Jurnal Aspikom, 3(4), 623-634.

Kusnianti, E (2013). Eksistensi Tradisi Nyadran di Gunung Balak dalam Arus Globalisasi. Universitas Negeri Yogyakarta.

Littlejohn, S. W., \& Foss, K. A (2011). Theories of Human Communication, United States of America. Waveland Press, Inc.

Nugroho, B. S (2015). Tradisi Upacara Nyadran di Desa Sonoageng Kecamatan Prambon Kabupaten Nganjuk Tahun 1994-2013. Universitas Jember. 
Parji, P. (2016). Socio-Cultural Values of Nyadran Traditional Ceremony in Tawun, Ngawi, East Java, Indonesia. SOSIOHUMANIKA, 9(2), 287-296.

Poranannond, P (2015). Tourism and the transformation of ritual practice with sand pagodas in Chiang Mai, Northern Thailand. Tourism Review, 70(3), 165-178.

Primagara, M. (2015). Pemaknaan Agama sebagai Hasil Interaksi Antar Anggota Komunitas Punk Muslim di Indonesia. Komunikator, 6(02), 1-7.

Priyanto, S., Moehadi, Pratitis, T., Mulyono, \& Sindu, G (1988). Dampak Modernisasi Terhadap Hubungan Kekerabatan di Daerah Jawa Tengah: Hubungan Kekerabatan. Direktorat Jenderal Kebudayaan.

Ross, M (2013). An Alternative Path: The Intellectual Legacy of James W. Carey. Master Theses. University of South Carolina, Columbia.

Schuler, B. (2014). Environmental and Climate Change in South and Southeast Asia: How are Local Cultures Coping?. Leiden: Brill.

Senft, G., \& Basso, E. B (2009). Ritual Communication. New York: Berg.

Wuryansari, H., Lestari, P., \& Sutrisno, I. (2014). Sadranan Sebagai Bentuk Komunikasi Sosial. Jurnal ASPIKOM, 2(3), 198-205.

Yusantari, Dhiajeng R (2017). Fungsi Tari Lengger Punjen dalam Upacara Nyadran Tenongan di Dusun Giyanti Desa Kadipaten Kecamatan Selomerto Kabupaten Wonosobo. Skripsi Sarjana, Yogyakarta, Institut Seni Indonesia. 